\title{
Enhancement of Nitrite Reduction Kinetics on Electrospun Pd-Carbon Nanomaterial Catalysts for Water Purification
}

\section{Supporting Information}

Tao Ye ${ }^{1}$, David P. Durkin ${ }^{2}$, Maocong Hu${ }^{3}$, Xianqin $\mathrm{Wang}^{3}$, Nathan A. Banek, ${ }^{4}$ Michael J. Wagner, ${ }^{4}$ Danmeng Shuai ${ }^{1 *}$

${ }^{1}$ Department of Civil and Environmental Engineering, The George Washington University, Washington, D.C, 20052, United States

${ }^{2}$ Department of Chemistry, Johns Hopkins University, Baltimore, Maryland, 21218, United States

${ }^{3}$ Department of Chemical, Biological and Pharmaceutical Engineering, New Jersey Institute of Technology, Newark, New Jersey, 07102, United States

${ }^{4}$ Department of Chemistry, The George Washington University, Washington, D.C, 20052, United States

* Corresponding Author: Phone: 202-994-0506, Email: danmengshuai@gwu.edu 


\section{EXPERIMENTAL SECTION}

Materials. $N, N$-Dimethylformamide (DMF, $\geq 99.8 \%$ ), polyacrylonitrile (PAN, $\mathrm{MW}=150,000$ ), sodium nitrite $\left(\mathrm{NaNO}_{2}, \geq 99.0 \%\right)$ were purchased from Sigma-Aldrich (MO, USA). Potassium phosphate dibasic anhydrous $\left(\mathrm{K}_{2} \mathrm{HPO}_{4}\right.$, USP grade), and potassium phosphate monobasic $\left(\mathrm{KH}_{2} \mathrm{PO}_{4}, \geq 99.0 \%\right)$ were obtained from Fisher Scientific (PA, USA). Palladium acetylacetonate [Pd(acac $\left.)_{2}\right]$ was obtained from VWR (PA, USA). Multi-walled carbon nanotubes (95+\%, OD 20-30 nm) were purchased from Nanostructure \& Amorphous Materials, Inc. (TX, USA). All chemicals were used as received. Aqueous solutions were made from ultrapure water $\left(18.2 \mathrm{M} \Omega \mathrm{cm}\right.$ at $\left.25^{\circ} \mathrm{C}\right)$ produced by a Millipore system (Direct-Q $3 \mathrm{UV}$, Millipore, USA).

Preparation of MWCNTs/Pd/CNFs. The catalysts were fabricated via single-spinneret electrospinning and post-thermal treatment. In a typical procedure, $0.143 \mathrm{~g}$ of $\mathrm{Pd}(\mathrm{acac})_{2}$ was first dissolved in $12 \mathrm{~g}$ of DMF by stirring at $80{ }^{\circ} \mathrm{C}$ for $20 \mathrm{~min}$, and next a certain amount of MWCNTs was dispersed in the solution by sonication (Branson Bransonic ${ }^{\mathrm{TM}} \mathrm{M}$ Series) for $2 \mathrm{~h}$. Finally, $1 \mathrm{~g}$ of PAN was added into the suspension of $\mathrm{Pd}(\mathrm{acac})_{2}$ and MWCNTs, and the suspension was stirred at $80{ }^{\circ} \mathrm{C}$ for $3 \mathrm{~h}$ and further sonicated (Ultrasonic, PH075EL) at $25^{\circ} \mathrm{C}$ for $12 \mathrm{~h}$. The prepared suspension was electrospun using a 12 $\mathrm{mL}$ syringe with a 25 gauge, blunt needle (NNC-PN-25GA, Nano NC) at a flow rate of $0.5 \mathrm{~mL} \mathrm{~h}^{-1}(\mathrm{NE}-$ 300, New Era Pump Systems Inc.) and under an applied voltage of $2 \mathrm{kV} \mathrm{cm}^{-1}$ (P030HP1, Acopian) in a closed chamber. A rotating drum wrapped with an aluminum foil with a rotating speed of $500 \mathrm{rpm}$ was used to collect the nanofibers. The as-spun nanofibers were dried in an oven (2000 series, Isotemp®, Fisher) at $60{ }^{\circ} \mathrm{C}$ for 1 day. To obtain the Pd loaded CNFs, the as-spun nanofibers were heated in a tube furnace (OTF-1200x-80, MTI Corporation) from room temperature to $230{ }^{\circ} \mathrm{C}$ at a rate of $2{ }^{\circ} \mathrm{C} \mathrm{min}^{-1}$ and stabilized at $230{ }^{\circ} \mathrm{C}$ for $3 \mathrm{~h}$ in air, heated up to $850{ }^{\circ} \mathrm{C}$ at $5{ }^{\circ} \mathrm{C} \mathrm{min}{ }^{-1}$ and held for $0.5 \mathrm{~h}$ in $\mathrm{N}_{2}$ for carbonization, followed by cooling down to $500{ }^{\circ} \mathrm{C}$ and holding at $500{ }^{\circ} \mathrm{C}$ for $2 \mathrm{~h}$ in $\mathrm{H}_{2}$ for the reduction of $\mathrm{Pd}^{2+}$ to $\mathrm{Pd}$.

Batch Reaction and Analytic Methods. The batch reaction experiments of nitrite hydrogenation were performed in a $50 \mathrm{~mL}$ glass bottle at $20 \pm 1{ }^{\circ} \mathrm{C}$ with continuous $\mathrm{H}_{2}$ flow $\left(150 \mathrm{~mL} \mathrm{~min}^{-1}\right)$ and mixing at ca. $500 \mathrm{rpm}$. The rate of hydrogen flow and mixing has been optimized to eliminate the limitation of reaction kinetics by hydrogen supply or external mass transfer. $25 \mathrm{mg}$ of the catalysts was dispersed by sonication for $20 \mathrm{~min}$ in a $50 \mathrm{~mL}$ phosphate buffer ( $1 \mathrm{mM}, \mathrm{pH} 7.3$ ) (i.e., catalyst loading of $0.5 \mathrm{~g} \mathrm{~L}^{-1}$ in the buffer), and pre-sparged with $\mathrm{H}_{2}$ for 20 min. Pre-sparging of $\mathrm{H}_{2}$ is necessary to reduce surface oxidized $\mathrm{Pd}$ resulted from catalyst storage in air, and it restores the catalytic activity. ${ }^{1}$ Reactions were initiated by introducing nitrite from a concentrated aqueous stock solution. Samples were taken at regular time intervals, filtered, and analyzed immediately. Nitrite adsorption by the catalysts was tested following similar procedure, except without $\mathrm{H}_{2}$ supply. No nitrite adsorption was observed. The nitrite anion was analyzed using ion chromatography (Dionex ICS-1100; Dionex IonPac ${ }^{\mathrm{TM}}$ AS18 column; $46 \mathrm{mM} \mathrm{NaOH}$ as eluent; $0.25 \mathrm{mLmin}^{-1}$ eluent flow rate; $25 \mu \mathrm{L}$ injection volume). Ammonia was measured by the Hach TNT 830 method (0.015-2 $\mathrm{mg} \mathrm{L}^{-1} \mathrm{NH}_{3}-\mathrm{N}$ ultralow range) using a Hach DR $6000 \mathrm{UV}$-vis spectrophotometer.

Characterization. The structure and morphology of catalysts were characterized by a Zeiss Supra 40 VP field-emission scanning electron microscope (SEM), and by a Philips CM 300 FEG transmission electron 
microscope (TEM) operated at $300 \mathrm{kV} .300$ fibers from at least 6 different locations were imaged and analyzed for fiber diameter with ImageJ. $500 \mathrm{Pd}$ nanoparticles from at least 10 different locations were imaged analyzed for particle size with ImageJ. X-ray photoelectron spectroscopy (XPS) was performed in a PHI 5400 XPS chamber under UHV conditions (pressure $<10^{-8}$ Torr). The materials measured with XPS were agglomerates with the scale of several $\mu \mathrm{m}$. Samples were probed with a $\mathrm{Mg} \mathrm{K} \alpha \mathrm{X}$-ray primary beam source $(1253.6 \mathrm{eV})$. Survey scans across the range of primary beam energies were collected, as well as multiplex scans of selected elemental binding energy regions. Peak positions were referenced to $\mathrm{C} 1 \mathrm{~s}$, $284.5 \mathrm{eV}$, and CasaXPS was used to determine chemical composition and atomic concentrations in the near surface region (within $10 \mathrm{~nm}$ ). CO chemisorption was measured in an AutoChem 2920 II (Micromeritics) equipped with a thermal conductivity detector (TCD). Hydrodynamic diameters and zeta potentials of the catalysts in the phosphate buffer $(1 \mathrm{mM}, \mathrm{pH} 7.3)$ were characterized by dynamic light scattering and electrophoresis on a Zetasizer nano ZS instrument (Malvern Instruments, U.K.). Braunauer-Emmitt-Teller (BET) surface area and porosity analyses were performed by liquid $\mathrm{N}_{2}$ adsorption/desorption using a Micromeritics TriStar 3000. Isotherm adsorption data for $\mathrm{P}_{0} / \mathrm{P}$ was recorded from 0.060-0.989. The volume of micropores was determined by t-plot analysis, and the volume of mesopores was determined by BJH analysis. Samples were degassed at $140{ }^{\circ} \mathrm{C}$ for $12 \mathrm{~h}$ under dynamic vacuum $\left(10^{-3}\right.$ Torr $)$ prior to analysis. One of the three sample measurement ports of the TriStar was equipped with an empty sample tube with which the saturation vapor pressure $\left(\mathrm{P}_{0}\right)$ of $\mathrm{N}_{2}$ was measured concurrently with each measurement of the equilibrium vapor pressure $(\mathrm{P})$ over the sample.

\section{RESULTS AND DISCUSSION SECTION}

Aqueous/Solid Mass Transfer Limitations (Evaluation of External Mass Transfer Rate). The aqueous/solid mass transfer rate constant for nitrite was calculated based on the literature. ${ }^{1,2}$ Slip velocity of the catalyst particles is first calculated and used to conservatively estimate the mass transfer rate between aqueous solution and the solid. Stokes' law was assumed to apply and the particle's slip velocity was calculated by:

$$
u_{t}=\frac{g d_{p}^{2}\left(\rho_{p}-\rho\right)}{18 \mu}
$$

in which $\mathrm{g}$ is standard gravity $\left(9.81 \mathrm{~m} \mathrm{~s}^{-2}\right), \rho_{\mathrm{p}}$ is average density of the catalysts and is assumed to be equal to that of activated carbon $\left(2 \mathrm{~g} \mathrm{~cm}^{-3}\right), \rho$ is water density $\left(1 \mathrm{~g} \mathrm{~cm}^{-3}\right.$ at $\left.20{ }^{\circ} \mathrm{C}\right), \mu$ is absolute viscosity of water $\left(1.002 \mathrm{~g} \mathrm{~m}^{-1} \mathrm{~s}^{-1}\right.$ at $\left.20^{\circ} \mathrm{C}\right)$, the hydrodynamic size $\mathrm{d}_{\mathrm{p}}$ of the catalysts was measured by dynamic light scattering and the average diameter is $3.58 \times 10^{3} \mathrm{~nm}$ for Pd/CNFs-2.5\%MWCNTs. Hence, the slip velocity is $6.97 \times 10^{-6} \mathrm{~m} \mathrm{~s}^{-1}$. The corresponding Reynolds number was calculated by the following expression:

$$
R_{e}=\frac{d_{p} u_{t}}{v}
$$

in which $v$ is kinematic viscosity of water $\left(1.003 \times 10^{-6} \mathrm{~m}^{2} \mathrm{~s}^{-1}\right.$ at $\left.20^{\circ} \mathrm{C}\right)$. The Reynolds number Re is $2.49 \times 10^{-5}<1$. This is indicative of laminar flow and Stokes law is applicable.

The Peclet number $(\mathrm{Pe})$ and Sherwood number $(\mathrm{Sh})$ were calculated based on the following equations: $:^{1,3}$

$$
P e=\frac{d_{p} u_{t}}{D}
$$




$$
S h=\frac{4}{P e} \ln \left(\frac{1}{1-P e / 2}\right)
$$

in which $\mathrm{D}$ is the nitrite diffusion coefficient in pure water $\left(1.9 \times 10^{-9} \mathrm{~m}^{2} \mathrm{~s}^{-1}\right)$. And the aqueous/solid mass transfer coefficient for nitrite is calculated according to the following expression: ${ }^{1}$

$$
k_{a q / s}=\frac{D}{d_{p}} S h=\frac{4 D}{P e \times d_{p}} \ln \left(\frac{1}{1-P e / 2}\right) ;
$$

The value of $k_{a q / s}$ is $0.01365 \mathrm{~m} \mathrm{~s}^{-1}$. The geometric surface area of the catalyst per volume of solution, a, is calculated according to the following expression by assuming the spherical structure of catalyst aggregates: ${ }^{2}$

$$
a=\frac{\text { total surface area }}{\text { total volume }}=\frac{S A_{p} \times M}{\rho_{p} \times V_{p}} \times \frac{1}{V_{R}} ;
$$

where $\mathrm{SA}_{\mathrm{p}}$ is the geometric surface area of one catalyst aggregate, $\mathrm{M}$ is the mass of catalyst in the reduction test $(0.025 \mathrm{~g}), \mathrm{V}_{\mathrm{p}}$ is the volume of one catalyst aggregate, and $\mathrm{V}_{\mathrm{R}}$ is the volume of the reaction solution $(50 \mathrm{~mL})$.

$$
a=\frac{4 \pi \times\left(3.58 \times 10^{-6} \mathrm{~m} / 2\right)^{2} \times 0.025 \mathrm{~g}}{2 \times 10^{6} \mathrm{~g} / \mathrm{m}^{3} \times \frac{4 \pi}{3}\left(3.58 \times 10^{-6} \mathrm{~m} / 2\right)^{3}} \times \frac{1}{50 \times 10^{-6} \mathrm{~m}^{3}}=4.19 \times 10^{3} \mathrm{~m}^{-1}
$$

The mass transfer rate constant was then calculated by multiplying the mass transfer coefficient by the geometric surface area of the catalyst per volume of solution:

$$
k_{a q / \mathrm{s}} a=0.01365 \mathrm{~m} / \mathrm{s} \times 4.19 \times 10^{3} \mathrm{~m}^{-1}=57.2 \mathrm{~s}^{-1}=3432 \mathrm{~min}^{-1}
$$

This value is significantly larger than the observed nitrite reduction rate constant $\left(0.0027 \mathrm{~min}^{-1}\right)$. Therefore, aqueous/solid mass transfer was not limiting the reaction rates.

Intraparticle Mass Transfer Resistance (Evaluation of Internal Mass Transfer Rate). The following criteria were used to determine whether pore diffusion resistance can significantly impact the measured reaction rates: 2,4

No pore diffusion resistance: $\frac{k_{o b s} L^{2}}{D_{e}}<1$;

Significant pore diffusion resistance: $\frac{k_{o b s} L^{2}}{D_{e}}>1$;

$\mathrm{L}$ and $D_{e}$ were estimated according to the following equations:

$$
\begin{aligned}
& D_{e}=\frac{D \theta}{\tau} ; \\
& L=\frac{d_{p}}{6} ;
\end{aligned}
$$

in which $\theta$ is the porosity of the catalyst particle ranging from 0.2 to $0.7, \tau$ is the tortuosity factor ranging from 2 to 10. In our calculation, conservative estimates of 0.2 and 10 will be used as values for $\theta$ and $\tau$, respectively. Therefore,

$$
\begin{gathered}
D_{e}=\frac{1.9 \times 10^{-9} \mathrm{~m}^{2} \mathrm{~s}^{-1} \times 0.2}{10}=3.8 \times 10^{-11} \mathrm{~m}^{2} \mathrm{~s}^{-1} \\
L=\frac{3.58 \times 10^{3} \mathrm{~nm}}{6}=5.97 \times 10^{-7} \mathrm{~m}
\end{gathered}
$$


The largest observed nitrite reduction rate constant was $0.0027 \mathrm{~min}^{-1}\left(4.5 \times 10^{-5} \mathrm{~s}^{-1}\right)$. This rate constant and the $\mathrm{L}$ and $D_{e}$ values calculated above were used to analyze the effects of pore diffusion.

$$
\frac{k_{o b s} L^{2}}{D_{e}}=\frac{4.5 \times 10^{-5} \mathrm{~s}^{-1} \times\left(5.97 \times 10^{-7} \mathrm{~m}\right)^{2}}{3.8 \times 10^{-11} \mathrm{~m}^{2} \mathrm{~s}^{-1}}=4.22 \times 10^{-7}<1
$$

Because the calculated value is significantly less than one, intraparticle mass transfer resistance has negligible influence on the measured reaction rates.

\section{Contribution of Element $H$ to the Calculated Pd Loading Based on XPS Results}

Table S1. Calculation of Pd loading based on XPS results.

\begin{tabular}{|c|c|c|c|c|c|c|c|c|c|c|}
\hline \multirow[t]{2}{*}{ Sample } & \multicolumn{4}{|c|}{ Atomic percentage } & \multicolumn{3}{|c|}{ Without $\mathrm{H}$ mass ${ }^{\mathrm{a}}$} & \multicolumn{3}{|c|}{ With H mass ${ }^{\mathrm{b}}$} \\
\hline & C 1s\% & $\mathrm{N} \mathrm{1s} \%$ & O 1s\% & $\mathrm{Pd} 3 \mathrm{~d} \%$ & $\mathrm{Pd} w \mathrm{t} \%$ & Average & $\begin{array}{l}\text { Standard } \\
\text { deviation }\end{array}$ & $\mathrm{Pd} w \mathrm{t} \%$ & Average & $\begin{array}{l}\text { Standard } \\
\text { deviation }\end{array}$ \\
\hline $\mathrm{Pd} / \mathrm{CNFs}$ & 86.6 & 4.23 & 8.34 & 0.83 & 6.7 & \multirow[t]{2}{*}{7.7} & \multirow[t]{2}{*}{1.4} & 6.3 & \multirow[t]{2}{*}{7.2} & \multirow[t]{2}{*}{1.3} \\
\hline $\mathrm{Pd} / \mathrm{CNF}$ duplicate & 84.9 & 4.6 & 9.45 & 1.1 & 8.7 & & & 8.2 & & \\
\hline $\begin{array}{l}\text { Pd/CNFs- } \\
2.5 \% \text { MWCNTs }\end{array}$ & 87.1 & 5.99 & 6.17 & 0.77 & 6.3 & \multirow[t]{2}{*}{5.1} & \multirow[t]{2}{*}{1.7} & 5.9 & \multirow[t]{2}{*}{4.8} & \multirow[t]{2}{*}{1.6} \\
\hline $\begin{array}{l}\text { Pd/CNFs- } \\
\text { 2.5\%MWCNTs } \\
\text { duplicate }\end{array}$ & 88.5 & 5.29 & 5.78 & 0.47 & 3.9 & & & 3.7 & & \\
\hline
\end{tabular}

${ }^{a}$ Not considering $\mathrm{H}$ for the calculation of the total mass of catalysts. ${ }^{\mathrm{b}}$ Assuming the $\mathrm{H}$ weight percentage as $5.7 \%$ as in polyacrylonitrile, which would be the highest end of $\mathrm{H}$ weight percentage of CNFs because annealing resulted in the loss of $\mathrm{H}^{5}$

After the conservative evaluation of $\mathrm{H}$ mass and its effect to the weight percentage of Pd in XPS analysis, the Pd loading of Pd/CNFs and Pd/CNFs-2.5\%MWCNTs is 0.5 and $0.3 \%$ (wt\%) larger when $\mathrm{H}$ mass was not considered, respectively. Therefore, the $\mathrm{H}$ content in CNFs has little significance for the determination of Pd loadings.

Pd Dispersion. Pd dispersion $(D)$ is defined as the number of Pd sites on nanoparticle surface calculated from TEM analysis, regardless of Pd surface coverage by carbon, to the number of Pd in bulk determined by ICP-MS. $D$ of Pd/CNFs and Pd/CNFs-2.5\%MWCNTs was calculated by assuming a cuboctahedral geometry of Pd nanoparticles because nanoparticles were near-spherical observed by TEM and the cuboctahedral geometry is the most stable. ${ }^{6}$ The calculation of the number of surface Pd sites $(N)$ followed the method described in our previous publication with a minor modification: ${ }^{6}$

$$
\begin{gathered}
N=\frac{m \times P d w t \%}{M_{P d}} N_{A} \frac{\sum_{i=1}^{j} N_{\text {surface }, i}}{\sum_{i=1}^{j} N_{\text {total }, i}} \\
=\frac{m \times P d w t \%}{M_{P d}} N_{A} \frac{\sum_{i=1}^{j}\left(10 v^{2}+2\right)}{\sum_{i=1}^{j}\left(10 \frac{v^{3}}{3}+5 v^{2}+11 \frac{v}{3}+1\right)} \\
N_{\text {bulk }}=\frac{m \times P d w t \%}{M_{P d}} N_{A} \quad(S 12)
\end{gathered}
$$




$$
\begin{aligned}
D=\frac{N}{N_{\text {bulk }}} & =\frac{\sum_{i=1}^{j}\left(10 v^{2}+2\right)}{\sum_{i=1}^{j}\left(10 \frac{v^{3}}{3}+5 v^{2}+11 \frac{v}{3}+1\right)} \\
v & =\frac{d}{2 d_{\text {metal-metal }}}-\frac{1}{2} \quad(S 14)
\end{aligned}
$$

where $m$ is the catalyst loading for each reduction experiment ( $25 \mathrm{mg}, \mathrm{Pd}$ plus support), $P d w t \%$ is the mass percentage of Pd determined by ICP-MS, $M_{P d}$ is the atomic weight of $\mathrm{Pd}\left(106.4 \mathrm{~g} \mathrm{~mol}^{-1}\right), N_{A}$ is Avogadro's number $\left(6.022 \times 10^{23} \mathrm{~mol}^{-1}\right), N_{\text {surface }, i}$ and $N_{\text {total }, i}$ are the number of surface Pd atoms on the Pd nanoparticle $i$ and the number of total $\mathrm{Pd}$ atoms in the $\mathrm{Pd}$ nanoparticle $i, j$ is the total number of $\mathrm{Pd}$ nanoparticles in one location (at least 10 different locations were imaged by TEM), $v$ is the order of a cuboctahedral nanoparticle, $d$ is the nanoparticle diameter characterized by TEM, and $d_{\text {metal-metal }}$ is the distance between metal atoms $(0.275 \mathrm{~nm}$ for Pd). Calculated $D$ of Pd/CNFs and Pd/CNFs-2.5\%MWCNTs is listed in Table S2.

Table S2. Calculation of Pd dispersion and exposed Pd to surface Pd percentage based on TEM, CO chemisorption, and ICP-MS results.

\begin{tabular}{c|c|c}
\hline Sample & Pd dispersion $(D, \%)$ & $\begin{array}{c}\text { Exposed Pd to surface Pd } \\
\text { percentage }(\%)^{\mathrm{a}}\end{array}$ \\
\hline $\mathrm{Pd} / \mathrm{CNFs}$ & $18.2 \pm 2.1$ & 3.5 \\
\hline $\mathrm{Pd} / \mathrm{CNFs}-2.5 \% \mathrm{MWCNTs}$ & $16.1 \pm 1.9$ & 11.2 \\
\hline
\end{tabular}

${ }^{a}$ Exposed Pd to surface Pd percentage is defined as the amount of exposed Pd that is accessible to reactants (determined by $\mathrm{CO}$ chemisorption) divided by the amount of surface Pd regardless of surface coverage by carbon (determined by TEM). In principle, it equals to Pd exposure (Table 2) divided by Pd dispersion.

Table S3. Zeta potential of Pd/CNFs, Pd/CNFs-1.5\%MWCNTs, and Pd/CNFs-2.5\%MWCNTs.

\begin{tabular}{c|c}
\hline Sample & Zeta potential $(\mathrm{mV})$ \\
\hline Pd/CNFs & $-54.3 \pm 1.5$ \\
\hline Pd/CNFs-1.5\%MWCNTs & $-49.7 \pm 0.7$ \\
\hline Pd/CNFs-2.5\%MWCNTs & $-46.4 \pm 1.0$ \\
\hline
\end{tabular}


Table S4. Comparison of reaction rate constant, TOF, and ammonia selectivity in catalytic hydrogenation of nitrite.

\begin{tabular}{|c|c|c|c|}
\hline Catalyst & 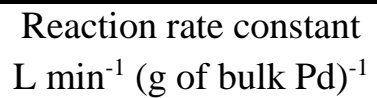 & $\begin{array}{l}\text { TOF } \\
\text { min }^{-1}\end{array}$ & $\begin{array}{c}\mathrm{NH}_{3} \text { selectivity } \\
\%\end{array}$ \\
\hline Pd/Activated Carbon ${ }^{a, 6}$ & $\mathrm{~N} / \mathrm{A}^{b}$ & 55 & 7 \\
\hline $\mathrm{Pd} / \mathrm{CNFs}^{a, 6}$ & 35.2 & 44 & 1.8 \\
\hline $\begin{array}{l}\text { Unsupported Pd } \\
\text { Nanoparticles }\end{array}$ & N/A & $0.013-0.063$ & N/A \\
\hline $\mathrm{Pd}-\mathrm{In} / \mathrm{Al}_{2} \mathrm{O}_{3}{ }^{d, 7}$ & 18.9 & 6.1 & 33.8 \\
\hline $\mathrm{Pd} / \mathrm{Al}_{2} \mathrm{O}_{3}{ }^{a, 6}$ & N/A & 4 & 2.3 \\
\hline $\mathrm{Pd} /$ Carbon Fiber ${ }^{e, 8}$ & 1.0 & 1.1 & 46 \\
\hline Pd/Pumice $\mathrm{e}^{f, 9}$ & N/A & 31.8 & 0.2 \\
\hline $\mathrm{Pd} / \mathrm{SiO}_{2}{ }^{f, 9}$ & N/A & 10.8 & N/A \\
\hline $\mathrm{Pd} / \mathrm{TiO}_{2}{ }^{g, 10}$ & N/A & N/A & 20 \\
\hline $\begin{array}{c}\text { Pd/Activated Carbon } \\
\text { Felt }^{h, 11}\end{array}$ & N/A & N/A & 3 \\
\hline $\mathrm{Pd} / \mathrm{CNFs}^{i, 12}$ & N/A & 9 & $75-82$ \\
\hline Pd/CNF Hairy Foam ${ }^{j, 13,14}$ & N/A & 1.26 & $87 \pm 3$ \\
\hline $\mathrm{Pd} / \mathrm{CNFs}-2.5 \% \mathrm{MWCNTs}{ }^{k}$ & $1.27 \pm 1.09$ & $0.7 \pm 0.5$ & 72 \\
\hline $\mathrm{Pd} / \mathrm{CNFs}^{k}$ & $0.05 \pm 0.01$ & $0.1 \pm 0.02$ & Below detection limit ${ }^{l}$ \\
\hline
\end{tabular}

${ }^{\mathrm{a}} \mathrm{H}_{2}$ flow rate of $135 \mathrm{~mL} \mathrm{~min}^{-1}, \mathrm{pH} 5$, initial nitrite concentration of $2 \mathrm{mM}$, and catalyst loading of $0.05 \mathrm{~g}$ $\mathrm{L}^{-1}$;

${ }^{\mathrm{b}}$ not available;

${ }^{\mathrm{c}} \mathrm{pH} 7$ (1 mM phosphate buffer), initial nitrite concentration of $0.1 \mathrm{mM}$, and catalyst loading of $0.2 \mathrm{mg}$ $\mathrm{Pd}$;

${ }^{\mathrm{d}} \mathrm{pH} 7$ (20 mM phosphate buffer), initial nitrite concentration of $0.08 \mathrm{mM}$, catalyst loading of $0.375 \mathrm{~g} \mathrm{~L}^{-1}$; ${ }^{\mathrm{e}} \mathrm{H}_{2}$ flow rate of $200 \mathrm{~mL} \mathrm{~min}^{-1}$, pH 6 (50 mM phosphate buffer), initial nitrite concentration of $0.217 \mathrm{mM}$; ${ }^{\mathrm{f}} \mathrm{H}_{2}$ flow rate of $400 \mathrm{~mL} \mathrm{~min}{ }^{-1}$, $\mathrm{pH} 5.5$, initial nitrite concentration of $1.3 \mathrm{mM}$;

${ }^{\mathrm{g}} \mathrm{H}_{2}$ flow rate of $200 \mathrm{~mL} \mathrm{~min}^{-1}$, $\mathrm{pH}$ 6, initial nitrite concentration of $0.65 \mathrm{mM}$, and $1 \mathrm{wt} \%$ of Pd loading; ${ }^{\mathrm{h}} \mathrm{H}_{2}$ flow rate of $400 \mathrm{~mL} \mathrm{~min}^{-1}, \mathrm{pH} 3-7$, initial nitrite concentration of $7.14 \mathrm{mM}$, catalyst loading of $2.5 \mathrm{~g}$ $\mathrm{L}^{-1}$;

${ }^{\mathrm{i}} \mathrm{H}_{2}$ partial pressure of 0.4 bar, $\mathrm{pH}$ 7, and initial nitrite concentration of $0.435 \mathrm{mM}$, $\mathrm{Pd}$ nanoparticles sizes in the range of 2 to $8 \mathrm{~nm}$;

${ }^{\mathrm{j}} \mathrm{H}_{2}$ partial pressure of 0.3 to 0.7 bar, $\mathrm{pH} 4.5-9$, and initial nitrite concentration of $0.217-0.435 \mathrm{mM}$;

${ }^{\mathrm{k}}$ this study, $\mathrm{pH} 7.3$, initial nitrite concentration of $0.1 \mathrm{mM}$ nitrite, catalyst loading of $0.5 \mathrm{~g} \mathrm{~L}^{-1}$;

${ }^{1}$ detection limit of $0.015-2 \mathrm{mg} \mathrm{L}^{-1} \mathrm{NH}_{3}-\mathrm{N}$. 
Calculation of Reaction Rate Constants and TOF . Nitrite reduction follows pseudo-first-order kinetics and the reaction rate constant $\left(\mathrm{k}, \mathrm{min}^{-1}\right)$ was obtained from linear regressions of the natural log of relative concentrations versus time plots. Catalyst loading normalized nitrite reduction rate constant was then calculated by dividing the reaction rate constant $\mathrm{k}$ by $\mathrm{Pd}$ loading in the reaction solution ( $\mathrm{g}$ of bulk $\mathrm{Pd} \mathrm{L} \mathrm{L}^{-}$ $\left.{ }^{1}\right) .{ }^{1}$ The initial turnover frequency $\left(\mathrm{TOF}_{0}, \mathrm{~min}^{-1}\right)$ was calculated by dividing the product of the reaction rate constant $\mathrm{k}$ and the initial nitrite concentration $\left(C_{0}, \mathrm{~mol} \mathrm{~L}^{-1}\right)$ by the concentration of surface $\mathrm{Pd}\left(C_{\text {surface }}\right.$ $\mathrm{Pd}$, mol L ${ }^{-1}$, determined by CO chemisorption): ${ }^{1}$

$$
T O F_{0}=\frac{k C_{0}}{C_{\text {surface Pd }}}
$$



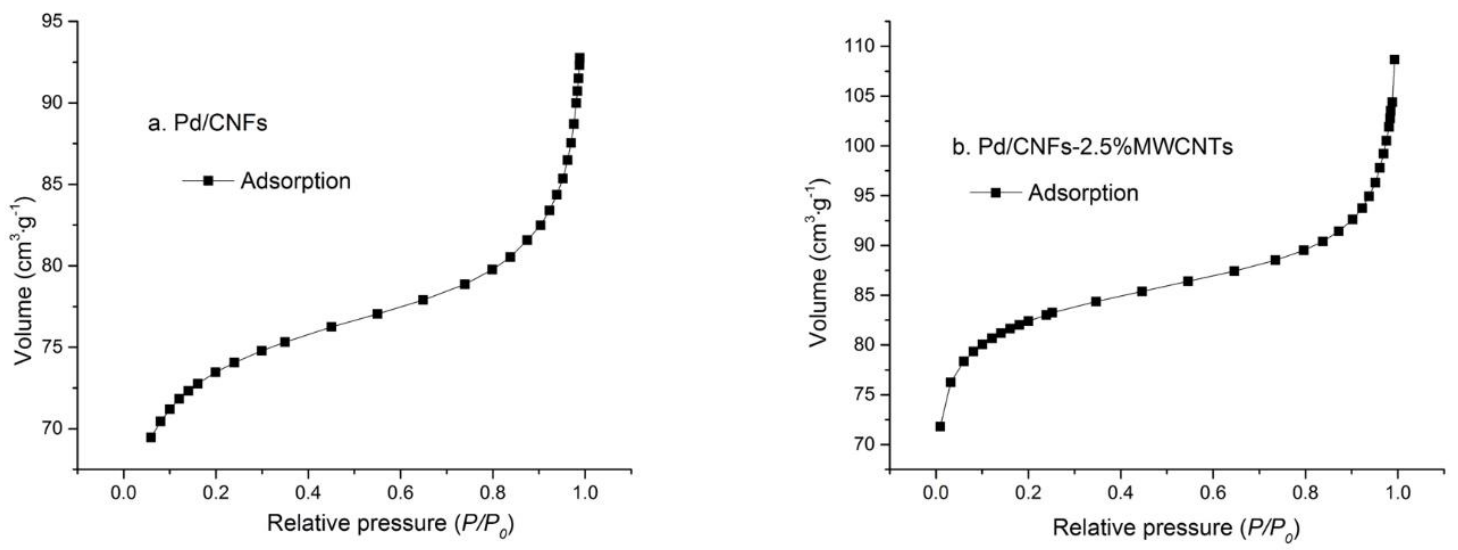

Figure S1. Liquid $\mathrm{N}_{2}$ adsorption isotherms of Pd/CNFs and Pd/CNFs-2.5\%MWCNTs.

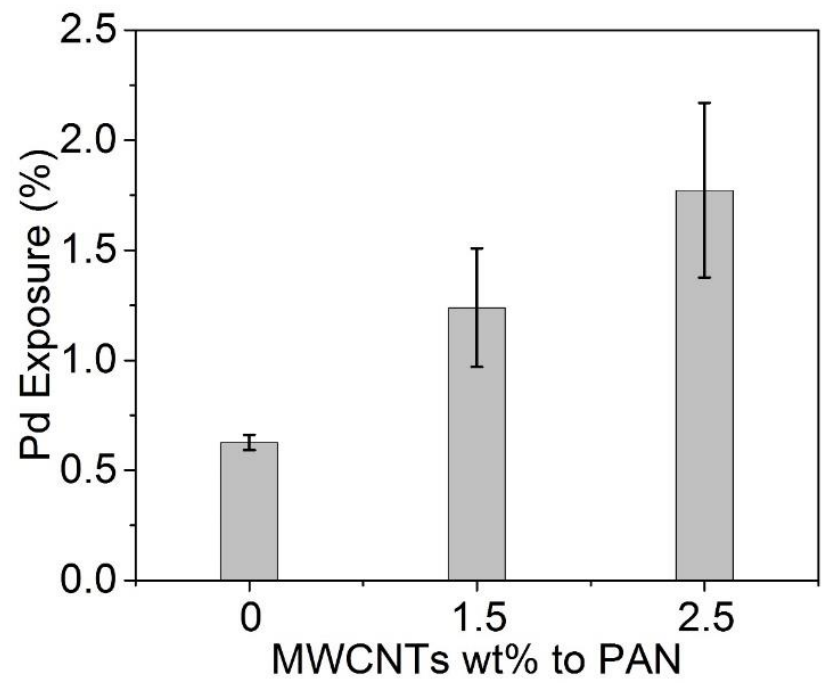

Figure S2. Effect of MWCNT addition on the Pd exposure of Pd/CNFs and Pd/CNFs-MWCNT catalysts. 


\section{References}

(1) Shuai, D.; McCalman, D. C.; Choe, J. K.; Shapley, J. R.; Schneider, W. F.; Werth, C. J. Structure Sensitivity Study of Waterborne Contaminant Hydrogenation Using Shape- and Size-Controlled Pd Nanoparticles. ACS Catal. 2013, 3, 453-463.

(2) Frierdich, A. J.; Shapley, J. R.; Strathmann, T. J. Rapid Reduction of N-Nitrosamine Disinfection Byproducts in Water with Hydrogen and Porous Nickel Catalysts. Environ. Sci. Technol. 2008, 42, $262-$ 269.

(3) Friedlander, S. K. Mass and Heat Transfer to Single Spheres and Cylinders at Low Reynolds Numbers. AIChE Journal 1957, 3, 43-48.

(4) Davie, M. G.; Reinhard, M.; Shapley, J. R. Metal-Catalyzed Reduction of N-Nitrosodimethylamine with Hydrogen in Water. Environ. Sci. Technol. 2006, 40, 7329-7335.

(5) Rahaman, M. S. A.; Ismail, A. F.; Mustafa, A. A Review of Heat Treatment on Polyacrylonitrile Fiber. Polym. Degrad. Stab. 2007, 92, 1421-1432.

(6) Shuai, D.; Choe, J. K.; Shapley, J. R.; Werth, C. J. Enhanced Activity and Selectivity of Carbon Nanofiber Supported Pd Catalysts for Nitrite Reduction. Environ. Sci. Technol. 2012, 46, 2847-2855.

(7) Zhang, R.; Shuai, D.; Guy, K. A.; Shapley, J. R.; Strathmann, T. J.; Werth, C. J. Elucidation of Nitrate Reduction Mechanisms on a Pd-In Bimetallic Catalyst using Isotope Labeled Nitrogen Species.

ChemCatChem 2013, 5, 313-321.

(8) Höller, V.; Rådevik, K.; Yuranov, I.; Kiwi-Minsker, L.; Renken, A. Reduction of Nitrite-Ions in Water over Pd-Supported on Structured Fibrous Materials. Appl. Catal., B. 2001, 32, 143-150.

(9) Deganello, F.; Liotta, L. F.; Macaluso, A.; Venezia, A. M.; Deganello, G. Catalytic Reduction of Nitrates and Nitrites in Water Solution on Pumice-Supported Pd-Cu Catalysts. Appl. Catal., B. 2000, 24, 265-273.

(10) Shin, H.; Jung, S.; Bae, S.; Lee, W.; Kim, H. Nitrite Reduction Mechanism on a Pd Surface. Environ. Sci. Technol. 2014, 48, 12768-12774.

(11) Bosko, M. L.; Marchesini, F. A.; Cornaglia, L. M.; Miró, E. E. Controlled Pd Deposition on Carbon Fibers by Electroless Plating for the Reduction of Nitrite in Water. Catal. Commun. 2011, 16, 189-193.

(12) Chinthaginjala, J. K.; Villa, A.; Su, D. S.; Mojet, B. L.; Lefferts, L. Nitrite Reduction over Pd Supported CNFs: Metal Particle Size Effect on Selectivity. Catal. Today 2012, 183, 119-123.

(13) Chinthaginjala, J. K.; Bitter, J. H.; Lefferts, L. Thin Layer of Carbon-Nano-Fibers (CNFs) as Catalyst Support for Fast Mass Transfer in Hydrogenation of Nitrite. Appl. Catal., A. 2010, 383, 24-32.

(14) Chinthaginjala, J. K.; Lefferts, L. Support Effect on Selectivity of Nitrite Reduction in Water. Appl. Catal., B. 2010, 101, 144-149. 